\title{
MODELLING THE PROBABILITY OF TOURISTS' RETURN INTENTION: THE CASE OF OPATIJA RIVIERA
}

\author{
Romina Alkier \\ Jasmina Okičić \\ Vedran Milojica
}

https://doi.org/10.20867/tosee.05.16

\begin{abstract}
Purpose - The purpose of this paper is to determine the key factors that influence the probability of tourists' return intention to the Opatija Riviera.

Methodology - A structured questionnaire with a 5 point Likert scale was used within this research. The authors used the descriptive statistics to determine the satisfaction with the destination attributes, and attitudes regarding the novelty of offer and possibility of future revisit. With the use of T-test a statistically significant difference was determined for the score for the accommodation capacities, natural resources and novelty. Correlation analysis was used to determine the association between accommodation, natural resources, cultural resources, novelty, and return intention. Logistic regression model was used to get a better understanding of the factors that may influence probability of tourists' return intention.

Findings - Results indicate high level of satisfaction of tourists with the accommodation offer and natural resources, while the results for cultural tourist resources were not up to expectations. The results for novelty are moderate and consistent with the results expressed about possible return intention to Opatija Riviera in the future, which indicates the need for significant improvements within the offer. The results of a logistic regression model determined that the best predictors for repeat visit of tourists are primarily accommodation services, followed by natural resources and finally novelty.

Contribution - Based on the findings acquired within this paper the authors proposed the guidelines for tourist offer improvement with a goal of increasing the satisfaction of tourists and stimulating them to revisit Opatija Riviera in the future.
\end{abstract}

Keywords probability, logistic regression, tourists' return intention, Opatija Riviera

\section{INTRODUCTION}

World tourism flows are registering a constant growth. Currently provisional figures indicate that 1,326 million of tourist arrivals were registered in 2017 which is a $7 \%$ of growth in relation to the year 2016 when 1,240 million of arrivals were registered. This has been registered as the highest increase since 2009 global crisis. Europe participated in the world arrivals with 671,7 million with the Southern Europe and the Mediterranean amounting 267,4 million. European Union members participated with 538,7 million (UNWTO, 2018). Despite constant positive trends of growth, world and European tourist market is continuously confronted with numerous challenges on daily basis, particularly in terms of development of new qualitative trends, respectively constant changes in tourist preferences which demand fast and timely reaction in terms of tourist offer improvement and achieving competitive advantages (Alkier et al., 2015). New 
ToSEE - Tourism in Southern and Eastern Europe, Vol. 5, pp. 17-29, 2019

R. Alkier, J. Okičić, V. Milojica: MODELLING THE PROBABILITY OF TOURISTS' RETURN ...

destinations are rising and developing on daily basis all over the world, which makes a game on the tourist market more intense; the time has arrived when attracting tourists to visit is simply not enough anymore. In order to achieve further success and competitive positioning on the tourist market, additional efforts need to be made towards not just attracting tourists to visit, but also provide them sufficient quality and unique experiences during their stay to the point that they will decide to revisit in the future and recommend to friends and family.

As one of the Croatian destinations with the longest tradition, Opatija Riviera has been registering positive trend of growth of tourist turnover over the years, although its business is still characterized significantly as seasonal (the most significant share is usually achieved in the summer period of the year). Despite this fact, Opatija Riviera represents an important factor of Primorje-Gorski Kotar and Croatia whose true potentials have not been fulfilled despite real opportunities (Cerović et al., 2015). Bearing in mind previously mentioned, and with a goal of improvement of current state of tourist offer, it is necessary to determine the tourist's level of satisfaction with the elements of the offer, and which are the key factors that influence on the probability of their future return to Opatija Riviera.

Therefore, the starting point of this research study is related to addressing the following question: What factors determine the probability of tourists' return intention to the Opatija Riviera? With regard to the research question, the central research hypothesis has been defined as follows: Probability of tourists' return intention to the Opatija Riviera is mainly determined by accommodation capacities, natural resources, destination's cultural resources and novelty.

The paper is structured as follows: after the introductory part the authors will provide an adequate theoretical background in which they will reflect on the newest and most important findings in determining the potential of tourist's revisiting a tourist destination. Following the authors will present the methodology and results of the empirical research conducted on the Opatija Riviera, and finally concluding remarks.

\section{THEORETICAL BACKGROUND}

The number of tourist destinations continues to grow on daily basis, and they are forced to participate in the market game, all with a goal of achieving and keeping the leading and competitive position. The key of achieving future success lies not only in attracting new tourists to visit a certain destination, but also in stimulating the present and the previous ones to revisit in the future (Vranešević et. al, 2018). In his study Marcussen (2011) emphasizes that in the majority of tourist markets a significant share of tourists are repeaters. In general it has been considered that tourist's satisfaction with the holiday and stay in a destination will result in a repeat visit, which has been proven in numerous previous studies. Even though current visitors decide not to revisit, their maximum satisfaction is very important due to many things, one being positive Word of Mouth which will have a significant influence on future potential tourists who so far never visited. 
ToSEE - Tourism in Southern and Eastern Europe, Vol. 5, pp. 17-29, 2019

R. Alkier, J. Okičić, V. Milojica: MODELLING THE PROBABILITY OF TOURISTS' RETURN ...

One of the biggest challenges with which contemporary tourist destinations are confronted today is provision and maintaining of top quality and diverse services, and as a result of that, tourist satisfaction. Provision of top quality services as well as achieving maximum customer satisfaction have been identified as key factors in the battle for competitive destination differentiation and customer retention (Avelini Holjevac et. al, 2009). After visiting the destination for the first time, tourists will be able to make an appropriate decision about the future visit based on their experiences during their stay, and also based on the information gathered from other sources. If tourists are sufficiently satisfied with their experiences during their stay in a destination, it is more likely that they will decide on a return visit, and spread positive (but also negative) experiences related to their stay (Kozak, 2001). Azim (2010) emphasizes in his work that experiencing satisfaction or dissatisfaction with the previous experiences during the stay in a destination is very important due to the fact that it may affect future decision about future revisit and tourist retention, or on the other hand it may result on a decision of changing a holiday destination. Impact of satisfaction on repeat business and customer loyalty differs from industry to an industry, and tourism is distinctively sensitive.

Over the years the importance of research aimed towards determining the level of satisfaction of tourists and its influence on repeat visits has been recognized and it has been undertaken constantly, from various points of view, all with a goal of determining the current state of tourist offer, and destination's business performance improvement. Zhang et al. (2018) in their research focused primarily towards exploring the relationships among the country image, destination image, memorable tourism experiences and revisit intention. The authors have determined that, although the relationship between satisfactory experience and tourist loyalty was weak, there was a strong relationship between forming of memorable tourism experiences and revisit intention of tourists. This indicates the importance of provision of unique and memorable experiences for tourists, in order to stimulate them to revisit the destination. Destination marketing management must not solely focus on provision of satisfaction, but also on provision of memorable experiences for tourists during they stay, which will in the end result in repeat visits. Mahdzar et al. (2015) used a similar approach in their research by trying to determine the influence of destination attributes, destination itself, and memorable tourism experiences on tourist's revisit intentions on the example of Mulu National Park in Malaysia. In their research the authors used a structured questionnaire, and the results were analyzed by using the descriptive statistics, confirmatory factor analysis and structural equation modelling. They determined that (and which) destination attributes, the destination itself, as well as memorable tourism experiences have a direct influence on tourist's future positive decision on revisiting. In their research Som et al. (2012) used factor analysis in order to identify the underlying dimensions of destination attributes of repeat visitors and motivational items. Descriptive statistics was used to calculate the mean scores for each tourist's perceptions on destination's loyalty items. In terms of Destination attributes the results indicate that for the respondents weather and natural attractions were the main factors to revisit Sabah, along with the destination image as the most important factor (due to the friendliness and hospitality of domestic people, local foods and good value for money). As far as repeat visitor's motives, the respondents evaluated highly possibility of relaxation and recreation, enhancing relations, sociability, fulfilling prestige as well as escaping the daily routine. In terms of loyalty, it has been determined that tourists plan to revisit Sabah in the future. Perović et 
ToSEE - Tourism in Southern and Eastern Europe, Vol. 5, pp. 17-29, 2019

R. Alkier, J. Okičić, V. Milojica: MODELLING THE PROBABILITY OF TOURISTS' RETURN ...

al. (2018) paid particular attention in their research to the mechanism which connects tangible and intangible elements, tourist's overall satisfaction, and their revisit intention. The determined results indicate that both intangible and tangible elements have an influence on tourist's future decision on revisiting a destination. In order to increase the possibility of the same, the authors propose that the future actions need to be made by the destination management, marketers and travel intermediaries towards forming developmental strategies on both elements equally. In their paper Alegre and Cladera (2007) focused their research primarily on studying the effect of previous visits and the level of satisfaction on the intention to return. Their secondary goal was to analyze how satisfaction with different aspects of a destination contributes towards total satisfaction. These information may be of significant importance when forming developmental strategies with a particular emphasis on increasing the level of satisfaction, which would hopefully result in revisit intentions. The authors proposed a model which explains both tourist's satisfaction with their stay and the revisit intention; it incorporates the level of satisfaction with different destination aspects (the perceived price/quality ratio, tourist motivations and the number of previous visits as explanatory variables. The main contribution of this model reflects in the fact that it takes into consideration two casual links with the number of previous visits, the first affecting overall satisfaction and the direct effect on tourist's revisit intention. Through model estimate it is possible to measure the total impact of previous visits on tourist's revision intention, and compare it with the satisfaction effect.

The main premise behind our theoretical concept is that various factors determine probability of tourists' return intention where we focus primarily on:

- accommodation capacities,

- natural resources,

- destination's cultural resources and

- novelty.

Figure 1 illustrates this theoretical concept.

\section{Figure 1: Illustration of the theoretical concept}

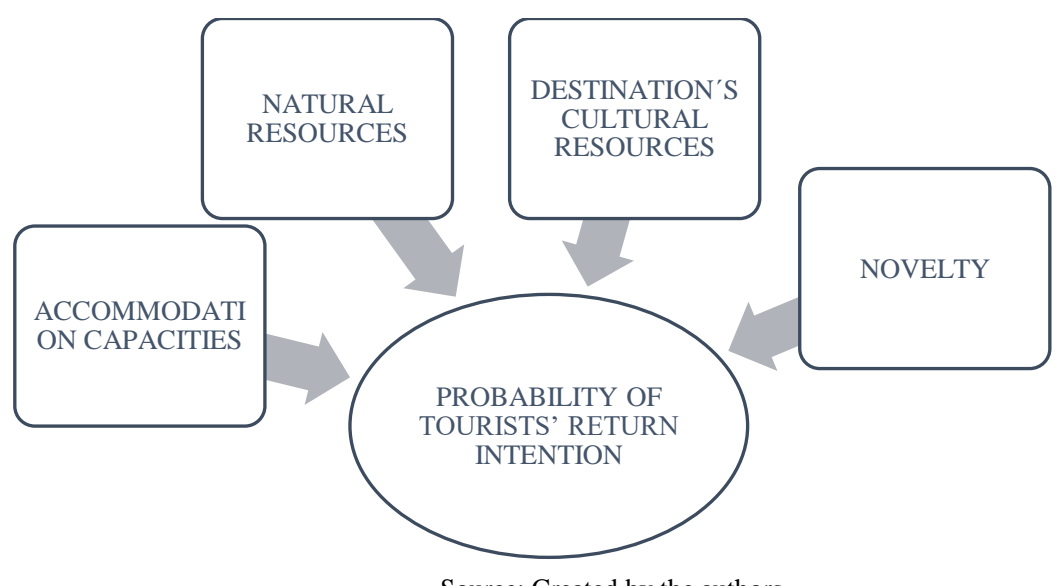

Source: Created by the authors 
ToSEE - Tourism in Southern and Eastern Europe, Vol. 5, pp. 17-29, 2019

R. Alkier, J. Okičić, V. Milojica: MODELLING THE PROBABILITY OF TOURISTS' RETURN ...

Previously presented findings clearly present the significant importance of undertaking this form of research in order to determine current attitudes of tourists towards the destination's tourist offer, as well their intention to revisit in the future, all with a goal of tourist offer improvement and achieving competitiveness on the tourist market.

\section{METHODOLOGY}

\subsection{Questionnaire design and sampling}

The research was conducted in the period of January and February 2019 in the destinations of Opatija Riviera by using a structured questionnaire. The respondents were tourists who were willing to participate in the research, and who were currently staying in Opatija Riviera. Totally 150 questionnaires were distributed in the field, and 102 were returned. After the evaluation it has been determined that totally 96 questionnaires were correctly filled, and by that adequate for further analysis. It is mandatory to emphasize that the sample size did not influence the relevance of this research, and that the same represents a good basis for future research. The questionnaire was prepared by adapting the methodology of Uran Maravić et. al (2015), Omerzel Gomzelj et al. (2008), Ghose and Johann (2018), TOMAS studies conducted and published by the Institute of Tourism (2017a, 2017b), and Researching tourism of a destination (2012) conducted and published by the Faculty of Tourism and Management in Opatija when preparing the questions for the destination attributes. Questions for novelty were adapted according to the methodology of Correia et. al. (2013), Zhang et. al. (2013) and Mahdzar et. al. (2015), and for return intention by Luo and Hsieh (2013).

\subsection{Research variables and methods}

The following variables were used for the purpose of this research:

- Tourist's return intention, as a binary dependent variable ( $D=1$ if the tourist has above average return intention, 0 otherwise. This variable was derived from the return intention score, i.e. its median;

- Accommodation capacities, natural resources, destination's cultural resources and novelty as independent variables.

The independent variables were measured using a 5-points Likert scale ranging from 1 ("strongly disagree") to 5 ("strongly agree"). In order to get a better understanding of the factors that may influence probability of tourists' return intention, the authors used a logistic regression model as a primarily methodological approach. The binary logistic regression equation is:

$$
\begin{aligned}
& e=\alpha+\beta_{1} \text { Accomodation Capaticies }+\beta_{2} \text { Natural Rescources } \\
& +\beta_{3} \text { Destination's cultural recources }+\beta_{4} \text { Novelty }
\end{aligned}
$$

where $e$ (tourists' above average return intention) is the logit (ln of the odds) of tourist above average intention to revisit Opatija Riviera. In order to estimate the model, logistic regression analyses procedures were made by using an SPSS version 21 . 
ToSEE - Tourism in Southern and Eastern Europe, Vol. 5, pp. 17-29, 2019

R. Alkier, J. Okičić, V. Milojica: MODELLING THE PROBABILITY OF TOURISTS' RETURN ...

\subsection{Instrument validity}

Before conducting the analysis, the authors did a reliability analysis, respectively they examined the reliability of used instruments by using Cronbach's alpha, $\alpha$ (or coefficient alpha) which is a measure of reliability that ranges from 0 to 1 , with values of .60 to .70 deemed the lower limit of acceptability (Hair et. al, 2014). Cronbach's alpha is sensitive to the number of items in a scale. So, a larger number of items can result in a larger, and a smaller number of items in a smaller Cronbach's alpha. The scores for each subscale were calculated as total score for the items representing each dimension. However, before that the authors assessed whether the subscales had satisfactory reliability (Table 2).

Table 1: Scale statistics

\begin{tabular}{|c|c|c|c|}
\hline Measure & Mean & SD & Cronbach's Alpha \\
\hline Accommodation Capacities & 19.75 & 2.80 & .769 \\
\hline Natural Resources & 26.28 & 3.38 & .887 \\
\hline Destination's Cultural Resources & 26.21 & 4.02 & .726 \\
\hline Novelty & 22.96 & 4.35 & .848 \\
\hline Return Intention & 43.22 & 7.76 & .915 \\
\hline
\end{tabular}

Source: Author's analysis

The data in the previous table indicate that all subscales had acceptable levels of reliability.

\subsection{Research design}

The research is organized in three phases. The first phase brings an analysis of basic parameters of descriptive statistics of the selected variables. These results have been considered of immense importance in terms of proper understanding of specificities of the sample. In the second phase, prior to estimating logistic regression model, the authors will use descriptive statistical analysis, an independent t-test and correlational analysis. In the last phase, the empirical results of the research have been presented.

\section{RESULTS AND DISCUSSION}

Within this chapter the authors will present the results of the empirical research conducted in the Opatija Riviera. The following table presents the basic sociodemographic characteristics of the sample. 
ToSEE - Tourism in Southern and Eastern Europe, Vol. 5, pp. 17-29, 2019

R. Alkier, J. Okičić, V. Milojica: MODELLING THE PROBABILITY OF TOURISTS' RETURN ...

Table 2: Overview of basic characteristics of the sample

\begin{tabular}{|c|c|c|c|}
\hline \multicolumn{2}{|r|}{ Characteristics } & Frequency & Percent \\
\hline \multirow{2}{*}{ Gender } & Male & 50 & 53.2 \\
\hline & Female & 44 & 46.8 \\
\hline \multirow{4}{*}{ Age } & Up to 35 & 28 & 29.2 \\
\hline & $36-40$ & 29 & 30.2 \\
\hline & $41-45$ & 20 & 20.8 \\
\hline & $46+$ & 19 & 19.8 \\
\hline \multirow{6}{*}{$\begin{array}{l}\text { The highest level of } \\
\text { completed education }\end{array}$} & Secondary school, 3-year program & 3 & 3.1 \\
\hline & Secondary school, 4-year program & 12 & 12.5 \\
\hline & Junior college (2-year university program) & 11 & 11.5 \\
\hline & University education, bachelor & 23 & 24.0 \\
\hline & University education, master's degree & 34 & 35.4 \\
\hline & University education, $\mathrm{PhD}$ & 13 & 13.5 \\
\hline \multirow{5}{*}{ Marital status } & Unmarried/single & 19 & 19.8 \\
\hline & Married & 55 & 57.3 \\
\hline & Widowed/Widower & 2 & 2.1 \\
\hline & Separated/Divorced & 2 & 2.1 \\
\hline & Domestic partnership & 18 & 18.8 \\
\hline \multirow{5}{*}{$\begin{array}{l}\text { Monthly income (in } \\
\text { Euros) }\end{array}$} & Up to 500,00 & 10 & 10.4 \\
\hline & $501,00-1.000,00$ & 20 & 20.8 \\
\hline & $1.001,00-1.500,00$ & 28 & 29.2 \\
\hline & $1.501,00-2.000,00$ & 19 & 19.8 \\
\hline & $2.001,00+$ & 19 & 19.8 \\
\hline
\end{tabular}

Source: Author's analysis

Within the sample $53.2 \%$ of the respondents were male, and $46.8 \%$ female. According to age, $30,2 \%$ belong to the age group $36-40$, followed by up to 35 years (29.2\%), $41-45$ $(20.8 \%)$ and $46+(19.8 \%)$. Most of them have a university degree $(35.4 \%)$, they are mostly married $(57.3 \%)$ with a high purchasing power. According to the country of origin, they were mainly from Slovenia (19.8\%), followed by Austria (15.6\%), Bosnia and Herzegovina (13.5\%), Germany (13.5\%) and Croatia (15.6\%), Italy (7.3\%), Serbia (6.3\%), Republic of Northern Macedonia (6.3\%) and Spain (1\%).

The following table presents a short overview of the selected variables for the analysis.

Table 3: Overview of selected variables

\begin{tabular}{|c|c|c|}
\hline Measure & Mean & SD \\
\hline ACCOMODATION CAPACITIES & \multicolumn{2}{|c|}{} \\
\hline The Structure of Accommodation Facilities & 4.14 & .59 \\
\hline The Quality of Accommodation Services & 4.26 & .65 \\
\hline Price of Accommodation Services & 4.12 & .78 \\
\hline Quality/Price Ratio for Accommodation Services & 4.21 & .74 \\
\hline The Existence of Distinctive International Accommodation Brands & 3.28 & 1.11 \\
\hline NATURAL RESOURCES & \multicolumn{2}{|}{} \\
\hline Climate & 4.64 & .56 \\
\hline Preservation of the environment & 4.31 & .82 \\
\hline
\end{tabular}


ToSEE - Tourism in Southern and Eastern Europe, Vol. 5, pp. 17-29, 2019

R. Alkier, J. Okičić, V. Milojica: MODELLING THE PROBABILITY OF TOURISTS’ RETURN ...

\begin{tabular}{|c|c|c|}
\hline Measure & Mean & SD \\
\hline Flora and Fauna & 4.43 & .59 \\
\hline Beauty of the landscape & 4.51 & .60 \\
\hline Sea cleanliness & 4.31 & .89 \\
\hline $\begin{array}{l}\text { Awareness of the importance of the destination's sustainable } \\
\text { development of tourism }\end{array}$ & 4.06 & .72 \\
\hline \multicolumn{3}{|l|}{ DESTINATION'S CULTURAL RESOURCES } \\
\hline People and traditions & 4.41 & .64 \\
\hline Architecture & 4.41 & .69 \\
\hline Historic sites & 4.27 & .73 \\
\hline Cultural heritage & 4.27 & .67 \\
\hline Theatres & 2.79 & 1.32 \\
\hline Galleries & 2.97 & 1.06 \\
\hline Museums & 2.96 & 1.05 \\
\hline \multicolumn{3}{|l|}{ NOVELTY } \\
\hline $\begin{array}{c}\text { Stay in Opatija Riviera made me experience the unexpected in a positive } \\
\text { way. }\end{array}$ & 3.52 & .82 \\
\hline My stay in Opatija Riviera was adventurous. & 3.14 & 1.01 \\
\hline I experienced a unique experience during my stay. & 3.55 & .84 \\
\hline $\begin{array}{l}\text { Experiences during my stay were different from any other previous } \\
\text { experiences. }\end{array}$ & 3.44 & .76 \\
\hline I experienced new things during my stay. & 3.30 & .71 \\
\hline I had an exciting experience. & 3.25 & .85 \\
\hline I had once in a lifetime experience. & 2.76 & 1.05 \\
\hline \multicolumn{3}{|l|}{ RETURN INTENTION } \\
\hline I would like to experience Opatija Riviera again. & 3.89 & .88 \\
\hline I feel familiar with the Opatija Riviera as a destination. & 3.65 & .82 \\
\hline $\begin{array}{c}\text { Staying in Opatija Riviera makes me feel relaxed physically and } \\
\text { mentally. }\end{array}$ & 3.82 & .85 \\
\hline $\begin{array}{l}\text { Costs associated with the Opatija Riviera as a destination are acceptable } \\
\text { for me. }\end{array}$ & 3.70 & .74 \\
\hline $\begin{array}{c}\text { Variety of activities and performances in Opatija Riviera stimulates me to } \\
\text { visit again. }\end{array}$ & 3.45 & .83 \\
\hline $\begin{array}{c}\text { I will revisit this destination in order to get away from the inadequate } \\
\text { climate. }\end{array}$ & 2.88 & 1.23 \\
\hline $\begin{array}{l}\text { Uniqueness and specificity of gastronomic offer stimulates me to revisit } \\
\text { Opatija Riviera. }\end{array}$ & 3.60 & .89 \\
\hline $\begin{array}{l}\text { Uniqueness, specificity and preservation of natural resources stimulates } \\
\text { me to revisit Opatija Riviera. }\end{array}$ & 3.68 & .90 \\
\hline $\begin{array}{l}\text { Uniqueness, specificity and preservation of cultural resources stimulates } \\
\text { me to revisit Opatija Riviera. }\end{array}$ & 3.64 & .92 \\
\hline $\begin{array}{l}\text { I would like to revisit Opatija Riviera due to it being a famous tourist } \\
\text { destination. }\end{array}$ & 3.39 & 1.03 \\
\hline $\begin{array}{l}\text { I would like to revisit Opatija Riviera due to its high quality restaurant } \\
\text { facilities. }\end{array}$ & 3.64 & .82 \\
\hline This destination is worth visiting. & 3.91 & .78 \\
\hline
\end{tabular}

Source: Author's analysis 
ToSEE - Tourism in Southern and Eastern Europe, Vol. 5, pp. 17-29, 2019

R. Alkier, J. Okičić, V. Milojica: MODELLING THE PROBABILITY OF TOURISTS' RETURN ...

The data in the previous table present the results of the descriptive statistics for the destination variables, novelty and their return intention. For the destination variables the authors will present the results for the accommodation capacities, natural resources, and cultural resources, considering that the data acquired proved to be sufficiently significant for the analysis.

The results for the accommodation capacities indicate that tourists are quite satisfied with its quality $(\overline{\mathrm{x}}=4.26$ and $\mathrm{SD}=0.65)$, the ratio of quality and price $(\overline{\mathrm{x}}=4.21$ and $\mathrm{SD}=0.74)$, accommodation structure $(\overline{\mathrm{x}}=4.14$ and $\mathrm{SD}=0.59)$, and finally charged price $(\overline{\mathrm{x}}=4.12$ and $\mathrm{SD}=0.78$ ). In terms of natural resources, tourists have shown the highest level of satisfaction with the appropriate climate $(\overline{\mathrm{x}}=4.64$ and $\mathrm{SD}=0.56)$, beautiful landscape $(\overline{\mathrm{x}}=4.51$ and $\mathrm{SD}=0.64)$, richness of Flora and Fauna in the destination $(\overline{\mathrm{x}}=4.43$ and $\mathrm{SD}=0.59)$, sea cleanliness $(\overline{\mathrm{x}}=4.31$ and $\mathrm{SD}=0.89)$, preservation of the environment $(\overline{\mathrm{x}}=4.31$ and $\mathrm{SD}=0.82$ ). The lowest mean was registered for the awareness of the importance of the destination's sustainable development of tourism in the destination $(\overline{\mathrm{x}}=4.06$ and $\mathrm{SD}=0.72$ ). The results for cultural resources indicate that the tourists have shown the highest satisfaction with the architecture $(\overline{\mathrm{x}}=4.41$ and $\mathrm{SD}=0.69)$, followed by the domestic people and traditions $(\overline{\mathrm{x}}=4.41$ and $\mathrm{SD}=64)$, visiting historical sights $(\overline{\mathrm{x}}=4.27$ and $\mathrm{SD}=0.73)$ and learning about cultural heritage $(\overline{\mathrm{x}}=4.27$ and $\mathrm{SD}=0.63)$. However, they also show a high level of dissatisfaction with the offer of galleries $(\overline{\mathrm{x}}=2.97$ and $\mathrm{SD}=1.06)$, museums $(\overline{\mathrm{x}}=2.96$ and $\mathrm{SD}=1.05)$ and theatres $(\overline{\mathrm{x}}=2.79$ and $\mathrm{SD}=1.32)$ within the destination, which implies significant need for offer improvements considering that these elements represent an important part of a contemporary tourist offer, and contribute to the competitiveness of a tourist destination.

Following the authors observed the tourist's attitudes about novelty of tourist offer, respectively in which relation do they consider it new, original, unusual, creative, modern, etc. All the registered results were below 4 which is quite unsatisfactory. The highest grade was given to experiencing a unique experience during their stay in a destination $(\overline{\mathrm{X}}=3.55$ and $\mathrm{SD}=0.84)$ and experiencing unexpected in positive way $(\overline{\mathrm{X}}=3.52$ and $\mathrm{SD}=0.82$ ). Lower mean was given to the element of experiences being different than any other experiences before $(\overline{\mathrm{x}}=3.44$ and $\mathrm{SD}=0.76)$, experiencing new things during stay $(\overline{\mathrm{x}}=3.30$ and $\mathrm{SD}=0.71)$, having exciting experiences $(\overline{\mathrm{x}}=3.25$ and $\mathrm{SD}=0.85)$, while the lowest mean was given to the their stay being adventurous $(\overline{\mathrm{x}}=3.14$ and $\mathrm{SD}=1.01)$ and experiencing a once in a lifetime experience $(\overline{\mathrm{x}}=2.76$ and $\mathrm{SD}=1.05)$. The results for tourist's future return intention are somewhat consistent with the novelty results, considering that that the results for all the means are below 4. The highest result was achieved for the element Destination being worth the visit $(\overline{\mathrm{x}}=3.91$ and $\mathrm{SD}=0.78)$, followed by the tendency of tourists to experience Opatija Riviera again ( $\bar{x}=3.89$ and $\mathrm{SD}=0.88$ ), and influence of stay on feeling relaxed physically and mentally $(\overline{\mathrm{x}}=3.82$ and $\mathrm{SD}=0.85$ ). Moderately lower means were registered for the elements relating costs associated with Opatija Riviera being acceptable $(\overline{\mathrm{x}}=3.70$ and $\mathrm{SD}=0.74)$, unique, specific and preserved natural resources being the stimulator for revisiting Opatija Riviera $(\overline{\mathrm{x}}=3.68$ and $\mathrm{SD}=0.90)$, sense of familiarity with Opatija Riviera as a destination $(\overline{\mathrm{x}}=3.65$ and $\mathrm{SD}=0.82$ ), unique, specific and preserved cultural resources being the stimulator for revisiting Opatija Riviera ( $\overline{\mathrm{x}}=3.64$ and $\mathrm{SD}=0.92$ ), tendency to revisit due to high quality restaurant service $(\overline{\mathrm{x}}=3.64$ and $\mathrm{SD}=0.82)$, and gastronomic offer being the reason to revisit $(\overline{\mathrm{x}}=3.60$ and $\mathrm{SD}=0.89)$. Lowest result was registered for the variety of activities and 
ToSEE - Tourism in Southern and Eastern Europe, Vol. 5, pp. 17-29, 2019

R. Alkier, J. Okičić, V. Milojica: MODELLING THE PROBABILITY OF TOURISTS' RETURN ...

performances as a factor for a revisit $(\overline{\mathrm{x}}=3.45$ and $\mathrm{SD}=0.83)$, revisit of a destination due to being famous $(\overline{\mathrm{x}}=3.39$ and $\mathrm{SD}=1.03)$, and revisit due to escape from inadequate climate $(\overline{\mathrm{x}}=2.88$ and $\mathrm{SD}=1.23)$.

To examine statistical differences between the means in scores for accommodation capacities, natural resources, destination's cultural resources and novelty, for two categories of tourists (tourist above average return intention vs. above average return intention), an independent $\mathrm{T}$ test was used. The test has revealed evidence of a statistically significant difference in mean accommodation capacities score $(p=.001)$; natural resources score $(\mathrm{p}=.000)$ and novelty $(\mathrm{p}=.000)$. Results of correlation analysis between selected measures are presented in the following table.

Table 4: Correlation matrix

\begin{tabular}{|c|c|c|c|c|c|}
\hline & $\begin{array}{l}\text { Accommodation } \\
\text { capacities }\end{array}$ & $\begin{array}{l}\text { Natural } \\
\text { resources }\end{array}$ & $\begin{array}{c}\text { Destination's } \\
\text { cultural } \\
\text { resources }\end{array}$ & Novelty & $\begin{array}{l}\text { Return } \\
\text { intention }\end{array}$ \\
\hline $\begin{array}{l}\text { Accommodation } \\
\text { capacities }\end{array}$ & 1 & $\begin{array}{l}.385^{* * * *} \\
(.001)\end{array}$ & $\begin{array}{l}.348^{* * *} \\
(.003)\end{array}$ & $\begin{array}{l}.323^{* * * *} \\
(.005)\end{array}$ & $\begin{array}{l}.403^{* * * *} \\
(.000)\end{array}$ \\
\hline Natural resources & & 1 & $\begin{array}{l}.187^{*} \\
\left(.092^{)}\right.\end{array}$ & $\begin{array}{l}.415^{* * *} \\
(.000)\end{array}$ & $\begin{array}{l}.493^{* * * *} \\
(.00)^{)}\end{array}$ \\
\hline $\begin{array}{c}\text { Destination's } \\
\text { cultural resources }\end{array}$ & & & 1 & $\begin{array}{l}.332^{* * * *} \\
(.003)\end{array}$ & $\begin{array}{l}.215^{*} \\
(.050)\end{array}$ \\
\hline Novelty & & & & 1 & $\begin{array}{l}.664^{* * * *} \\
(.005)\end{array}$ \\
\hline Return intention & & & & & 1 \\
\hline
\end{tabular}

Note: $* / * * / * * *$ significantly different from 0 at the $0.1 / 0.05 / 0.01$ levels, respectively, two-tailed test Source: Author's analysis

Results of the Pearson correlation indicated that there was a significant association between accommodation capacities, natural resources, destination's cultural resources, novelty and return intention. In order to evaluate the impact of factors that may influence tourists' return intention logistic regression model was used. Without any predictor in the model $62.5 \%$ of cases would be correctly classified as employed or unemployed. We conducted Omnibus test which shows that the model is having predictive capacity. The entire model (with all predictors included) is statistically significant, $\chi 2(1, \mathrm{~N}=96)=$ $37.624, \mathrm{p}=.000$. Previously mentioned is confirmed by the Hosmer and Lemeshow test with $\chi^{2}(8, \mathrm{~N}=96)=9.157, \mathrm{p}=.329$. Model correctly classifies $85.9 \%$ of cases. The following table displays model performance analysis.

Table 5: Model performance analysis

\begin{tabular}{|c|c|c|c|c|c|}
\hline Independent variable & B & S.E. & Wald & Sig. & Exp(B) \\
\hline Accommodation capacities & .388 & .174 & 4.986 & .026 & 1.474 \\
\hline Natural resources & .312 & .137 & 5.185 & .023 & 1.366 \\
\hline Destination's cultural resources & -.106 & .117 & .818 & .366 & .899 \\
\hline Novelty & .282 & .130 & 4.693 & .030 & 1.326 \\
\hline Constant & -20.317 & 5.510 & 13.595 & .000 & .000 \\
\hline
\end{tabular}

Source: Author's analysis 
ToSEE - Tourism in Southern and Eastern Europe, Vol. 5, pp. 17-29, 2019

R. Alkier, J. Okičić, V. Milojica: MODELLING THE PROBABILITY OF TOURISTS' RETURN ...

According to the results presented in the previous table, three independent variables were statistically significant in the model (accommodation capacities, natural resources and novelty). Based on the estimated odds ratios, best predictor that the tourist's will have above average intention to revisit Opatija Riviera refers to accommodation capacities. The second best predictor refers to natural resources and the next best predictor is novelty. Thus, for each increase in accommodation capacities score, natural resources score and novelty score, the odds of being a tourist with above average intention to revisit Opatija Riviera increase by a factor of $1.474,1.366$ and 1.326 , respectively.

\section{DEVELOPMENTAL GUIDELINES OF FURTHER IMPROVEMENT OF OPATIJA RIVIERA'S TOURIST OFFER}

Based on the results of the empirical research presented in the previous chapter the authors propose the following developmental guidelines with a goal of improvement of current state of tourist offer improvement:

- Elements of tourist product need to be continuously harmonized with the needs of a contemporary tourist, which is why it is important to constantly the monitor the satisfaction level of tourists with the services and stay in the destination, and its performances on the tourist market;

- Despite Accommodation capacities receiving a high grade, further investments need to be made to keep the current level of quality and diversity, and aim towards further improvements according to the world examples of good practice;

- It is necessary to form and introduce new tourist products of additional value for the tourist destination (developed according to the preferences of contemporary tourists, during which it is important not to disturb the authencity of a tourist destination), all with a goal of improving the destination's novelty;

- Natural resources and cultural heritage must be preserved by any cost which automatically implies implementation of sustainability principles;

- Innovativeness, creativity and knowledge must be implemented more and used as a factor of achieving future success, stronger recognizability of a tourist product and the destination in total, and competitiveness on the tourist market;

- Destination's cultural heritage needs to be included more in the tourist product (particular accent on inclusion of museums and galleries through organization of cultural events);

- Theatres could be used as "live stages" through which it could be possible to present the history and tradition of a destination and enable for visitors to "feel the uniqueness";

- It is advisable to pay additional attention towards development of tourist offer for specific segments (children, families, seniors, etc.);

- The accent must constantly be on formation and offering unique experiences which would result in positive decision when rethinking about possible return intention to the destination. 
ToSEE - Tourism in Southern and Eastern Europe, Vol. 5, pp. 17-29, 2019

R. Alkier, J. Okičić, V. Milojica: MODELLING THE PROBABILITY OF TOURISTS' RETURN ...

Implementation of previously proposed developmental guidelines will most certainly have a big impact on tourist offer improvement, which will undoubtedly manifest on positive decision of tourists when considering to revisit Opatija Riviera as a tourist destination.

\section{CONCLUSION}

Opatija Riviera represents one of the most important Croatian tourist destinations considering its long tourist tradition, and destination particularities. This has been witnessed by a growing number of tourists who choose to visit it repeatedly. Results of the empirical research have determined the level of satisfaction of tourists with the elements of tourist offer of Opatija Riviera and their attitudes about the novelty of tourist offer, all with a goal of testing the possibility whether they would and if yes, to which extent be interested in visiting Opatija Riviera again. The results of a logistic regression model indicated that the strongest statistical significance was determined for the independent variables accommodation capacities (being the best predictor of future return visit), followed by natural resources, and finally novelty. Further improvements need to be made within the tourist offer, according to the previously proposed developmental guidelines. However, the authors must emphasize some limitations within this paper. The research has been conducted in a preseason on a small statistical sample. In order to obtain more clearer results, it is necessary to repeat the survey on a bigger sample, and to include larger number of variables.

\section{REFERENCES}

Alegre, J. and Cladera, M. (2007), "Analysing the effect of satisfaction and previous visits on tourist intentions to return”, European Journal of Marketing, Vol. 43, No. 5/6, pp. 670-685, https://doi.org/10.1108/03090560910946990

Alkier, R., Drpić, D. and Milojica, V. (2015), "Doprinos marketinških strategija u ostvarenju konkurentne ponude nautičkog turizma Republike Hrvatske", Pomorski zbornik, Vol. 49-50, No. 1, pp. 181-205.

Avelini Holjevac, I., Marković, S. and Raspor, S. (2009), "Customer satisfaction measurement in hotel industry: Content analysis study", In Proceedings of 4th International Scientific Conference "Planning for the future learning from the past: Contemporary Developments in Tourism, Travel \& Hospitality", April 3-5, 2009, Rhones Islands, Greece, pp. 1-10.

Azim, T.S.A. (2010), "Evaluating the Relationship Between the Socio-Demographic Variabes, Travel Experience And The Probability to Return to Destintation The Case of French Tourists in Egypt", Tourismos: An International Multidisciplinary Journal of Tourism, Vol. 5, No. 1, pp. 111-129.

Cerović, Lj., Drpić, D. and Milojica, V. (2015), “The Possibilities for Repositioning of the Opatija Riviera's Tourism Offer”, UTMS Journal of Economics, Vol. 5, No. 1, pp. 121-130.

Correia, A., Kozak, M. and Ferradeira, J. (2013), "From tourist motivations to tourist satisfaction", International Journal of Culture, Tourism and Hospitality Research, Vol. 7, No. 4, pp. 411-424, https://doi.org/10.1108/IJCTHR-05-2012-0022

Ghose, S. and Johann, M. (2018), "Measuring tourist satisfaction with destination attributes", Journal of Management and Financial Sciences of Warsaw School of Economics, Vol. 11, No. 34, pp. 9-22.

Hair, J.F., Black, W.C., Babin, B.J. \& Anderson, R.E. (2014), Multivariate Data Analysis. Pearson Education Limited, Harlow-Essex, UK.

Institute for Tourism. (2018a), TOMAS Ljeto 2017 Stavovi i potrošnja turista u Hrvatskoj [TOMAS Summer 2017 Attitudes and Consumption of Tourists in Croatia], Institute for Tourism, Zagreb, Croatia

Institute for Tourism. (2018b), TOMAS Nautika Jahting [TOMAS Nautica Yachting], Institute for Tourism, Zagreb, Croatia.

Kozak, M. (2001), "Repeaters' Behavior at Two Distinct Destinations”, Annals of Tourism Research, Vol. 28 No. 3, pp. 784-807, https://doi.org/10.1016/S0160-7383(00)00078-5 
ToSEE - Tourism in Southern and Eastern Europe, Vol. 5, pp. 17-29, 2019

R. Alkier, J. Okičić, V. Milojica: MODELLING THE PROBABILITY OF TOURISTS' RETURN ...

Luo, S.J. and Hsieh, L.Y. (2013), "Reconstructing Revisit Intention Scale in Tourism", Journal of Applied Sciences Vol. 13, No. 18, pp. 3638-3648, DOI: 10.3923/jas.2013.3638.3648

Mahdzar, M., Shuib, A., Ramachandran, S. and Afandi, S.H.M. (2015), "The Role of Destination Attributes and Memorable Tourism Experience in Understanding Tourist Revisit Intentions", AmericanEurasian Journal of Agricultural \& Environmental Sciences, Vol. 15, pp. 32-39.

Marcussen, C. (2011), "Determinants of tourist satisfaction and intention to return", TOURISM: International Scientific-Professional Journal, Vol. 59, No. 2, pp. 203-221.

N.A. (2012), Researching tourism of a destination [Istraživanje turizma destinacije]. University of Rijeka Faculty of Tourism and Hospitality Management Opatija. Ed. Blažević Branko and Peršić Milena.

Omerzel Gomezelj, D. and Mihalič, T. (2008), "Destination Competitiveness: applying different models, the case of Slovenia", Tourism Management, Vol. 29, No. 2, pp. 294-307, https://doi.org/10.1016/j.tourman.2007.03.009

Perovic, Đ., Moric, I., Pekovic, S., Stanovcic, T., Roblek, V., Pejic Bach, M. (2018), "The antecedents of tourist repeat visits intention: systematic approach", Kybernetes, Vol. 47, No. 9, pp. 1857-1871, https://doi.org/10.1108/K-12-2017-0480

Som, A.P.M., Marzuki, A., Yousefi, M. and AbuKhalifeh, A.N. (2012), "Factors Influencing Visitors' Revisit Behavioral Intentions: A Case Study of Sabah, Malaysia", International Journal of Marketing Studies, Vol. 4, No. 4, pp. 39-50, doi:10.5539/ijms.v4n4p39

United Nations World Tourism Organization (2018), UNWTO Tourism Highlights 2018 Edition, viewed 01 January 2019, https://www.e-unwto.org/doi/pdf/10.18111/9789284419876

Uran Maravić, M., Gračan, D. and Zadel, Z. (2015), "A Comparison of the Competitiveness of the Two Coastal Tourist Destinations", Our Sea International Journal of Maritime Science and Technology, Vol. 62, No. 4, pp. 120-126.

Vranešević, T., Pandža Bajs, I. and Mandić, M. (2018), Upravljanje zadovoljstvom klijenta [Managing Client's Satisfaction], Accent d.o.o., Zagreb, Croatia.

Zhang, H., Wu, Y. and Buhalis, D. (2018), "A model of perceived image, memorable tourism experiences and revisit intention", Journal of Destination Marketing and Management, Vol. 8, pp. 326-336, https://doi.org/10.1016/j.jdmm.2017.06.004

Romina Alkier, $\mathrm{PhD}$, Associate Professor

University of Rijeka

Faculty of Tourism and Hospitality Management

Department of Tourism

Primorska 42, 51410 Opatija, Croatia

Tel: +385 51 294-718

E-mail: rominaa@fthm.hr

Jasmina Okičić, PhD, Associate Professor

Faculty of Economics in Tuzla

Univerzitetska 8, 75000 Tuzla, Bosna i Hercegovina

Tel: +387 35 320-820

E-mail: jasmina.okicic@untz.ba

Vedran Milojica, MA, PhD Student

University of Rijeka

Faculty of Tourism and Hospitality Management

Primorska 42, 51410 Opatija, Croatia

E-mail: vedran.milojica@gmail.com 